\title{
Türkiye'nin Bilgi Toplumu Politikasında Kütüphane Kurumuna Yaklaşım
}

\section{The Approach to the Institution of Library in Information Society Policy of Turkey}

\author{
Bülent YILMAZ*
}

\begin{abstract}
Öz
Bu çalışmada, Türkiye'nin Bilgi Toplumu Politikasında kütüphane kurumuna ilişkin yaklaşımın değerlendirilmesi amaçlanmıştır. Bu çerçevede, konunun önce kuramsal çerçevesi çizilmiş, daha sonra Türkiyénin ulusal planlama örgütü olan Devlet Planlama Teşkilatı́nın konu ile ilgili olarak 2003 yılından bu yana yayımladığı "e-Türkiye Girişimi Eylem Planı-2002"; "e-Dönüşüm Türkiye Projesi Kısa Dönem Eylem Planı (2003-2004)"; "e-Dönüşüm Türkiye Projesi 2005 Eylem Planı"; "Bilgi Toplumu Stratejisi (2006-2010)"; "Bilgi Toplumu Stratejisi Eylem Planı (2006-2010)" adlı politika belgeleri irdelenmiştir.

Araştırma sonucunda, kütüphane kurumunun Türkiye'nin Bilgi Toplumu Politikasında organik bir bileşen olarak görülmediği; sözü edilen politikada bu kurumu toplumsal, kültürel ve eğitimsel bağlamlarda doğru algılayan, bütünsel bir yaklaşım bulunmadığı anlaşılımıştır. Sorunun kütüphaneler açısından çözümü için kütüphanecilerin bu konudaki bilimsel yaklaşımlarını ortaya koymaları ve Türkiye'de Bilgi Toplumu Politikası oluşturma-uygulama süreçlerine etkin ve sürekli olarak katılmaları önerilmiştir.
\end{abstract}

Anahtar Sözcükler: Bilgi toplumu, Bilgi politikaları, Kütüphane, Türkiye

\begin{abstract}
This study aims to evaluate the approach taken by the State regarding "Library as an Institution" in determining the Information Society Policy of Turkey. Within this framework, first the theoretical aspects of the issue are explained, then strategy documents, published by the State Planning Organization since 2003, were examined, namely "e-Turkey Enterprise Action Plan-2002"; "e-Transition Turkey Project Short-Term Action Plan (2003-2004)"; e-Transition Turkey Project 2005 Action Plan"; "Information Society Strategy (2006-2010)"; "Information Society Strategy Action Plan (2006-2010)".
\end{abstract}

As a result of the research done, it was determined that the "Library" was not assessed to be a basic component in determining the Information Society Policy of Turkey; there was no integrated approach in considering this institution as being effective as a social, cultural and

* Prof. Dr.; Hacettepe Üniversitesi Bilgi ve Belge Yönetimi Bölümü, Beytepe, Ankara. (byilmaz@hacettepe.edu.tr) 
educational factor in the national policy strategy. The solution to this problem in terms of libraries, as suggested, is that librarians should offer objective and methodical approaches to this critical issue and they should actively and constantly participate in the creation-application processes in regard to the Information Society Policy in Turkey.

Keywords: Information society, Information policies, Library, Turkey

\section{Giriş}

1970'li yıllarda ortaya çıkan ve özellikle 1990'lardan sonra dünyadaki toplumsal değişimi anlatmakta neredeyse temel kavram olarak kullanılmaya başlanan Bilgi Toplumu Türkiye'ye de yansıyan etkileriyle günümüzün ana gerçekliği sayılmaktadır. Bilginin toplumsal yaşamın her alanındaki belirleyiciliği ve dolayısıyla gerek toplumlar ve gerekse bireyler için zorunlu gereksinim durumuna gelişi, üretim hızı ve miktarındaki kestirilemeyen artış, meta niteliğine dönüşmesi, bilgi ve iletişim teknolojilerinin bilginin hem üretimini hem de kullanımını niteliksel olarak değiştiren yapısı kavrama kaynaklık eden temel gelişmeler olarak kabul edilmektedir.

Ülkelerin, sözü edilen toplumsal dönüşüm sürecine uyum sağlayabilmeleri için bu süreci doğru okuyup algılamaları ve sürecin gerektirdiği hedefleri belirleyerek, eylemler planlaması zorunlu görünmektedir. Bu, "hedefler koyma ve eylemler planlama/ gerçekleştirme süreci"strateji ya da politika anlamına gelmektedir. Stratejik davranmak ya da aynı anlama gelmek üzere her toplumsal alan için politikalar üretmekgünümüzdeki çağdaş toplumların göz ardı edemeyeceği, bunun da ötesinde sahip olmak zorunda kaldıkları bir yaklaşım biçimidir. Bu bağlamda, Bilgi Toplumu olarak adlandıılan toplumsal dönüşüme ilişkin doğru kavrayış ve davranışıiçeren politika ve/veya stratejiler geliştirilmesi büyük önem taşımaktadır.

Bilgi olgusu üzerine temellenen kütüphane kurumu, yalnızca bu niteliği ile dahi Bilgi Toplumunun organik bir parçası olarak kabul edilmek durumundadır. Böyle bakıldığında, bilgiyi toplayan, düzenleyen ve eriştiren başlıca kurumlar olan kütüphanelerin, Bilgi Toplumuna ilişkin olarak geliştirilecek politikalarda öncelikle düşünülmesi zorunlu görünmektedir.

Bu çalışma, Türkiye'de başıca politika/strateji geliştirme kuruluşu olan Devlet Planlama Teşkilatı'nın, Bilgi Toplumuna yönelik politikalarında kütüphane kurumunun algılanış ve yer alış düzey ve niteliğini irdelemeyi amaçlamaktadır. Bu irdeleme, birinci bölümde ortaya konulacak kuramsal temele dayandırılmaya çalışılacaktır.

\section{Bilgi Toplumu, Bilgi Politikası ve Kütüphane Kurumu}

Bilgi Toplumu, dünyada özellikle son otuz yıldır yaşanan toplumsal değişimi adlandırmakta kullanılan bir kavramdır. Ekonomik, kültürel ve teknolojik boyutlara sahip bu değişim sürecinin etkilediği ve hatta kapsadığı kurumların başında doğal 
olarak kütüphaneler gelmektedir. Bilginin üretiminden tüketimine kadar geçen süreçte önemli roller oynayan kütüphaneler, bir yandan Bilgi Toplumunun ürünü iken, diğer yandan bu toplumu besleyen kurumlar arasında yer almaktadır.

Genelde II. Dünya Savaşı sonrasından söz edilmekle birlikte, Bilgi Toplumunun belirli bir olaya dayalı başlangıcı olarak 1957 yılında ABD'de ilk defa beyaz yakalı işçilerin sayısının mavi yakalı işçilerin sayısını geçmesi kabul edilmektedir. Çok genel olarak tanımlamak gerekirse, Bilgi Toplumu, "iktisadi, sosyal, kültürel ve siyasi hayatın bir unsuru olarak bilgiyi yoğun şekilde kullanan toplum"dur (Akın, 2005; Akın, 2007, s.1). Benzer bir yaklaşımla, Bilgi Toplumu, "En temel meta konumundaki bilginin, yaşamın her alanında her geçen gün artan bir hızla ve küresel ölçekte, sürekli akıp arttığı, esneklik, çeşitlilik, yaratıcılık, yenilik gibi kavramların belirleyici olduğu, eğitimli bireyin ön plana çıktığı etkileşimi son derece yüksek, şebeke yapısında bir toplum" olarak tanımlamaktadır. (Gültan, 2003 s.47). Toffler (1981, s.32) üç önemli değişim dalgasından söz ederken, ilkini i.Ö. 10 binlerde başlatılan tarım devrimi, ikincisini 17. yüzyılın sonlarından itibaren başlatılan sanayi devrimi, sonuncusunun da II. Dünya Savaşı yıllarından sonra başlayan Bilgi Toplumu ya da Bilgi Çağı olarak belirtmektedir. Toffler'in sınıflandırmasına göre, sanayi toplumunda üretim unsurları olarak emek, sermaye ve doğal kaynaklar ağırlıklı iken, üçüncü dalga toplumlarda özellikle bilgi ve imaj, kültür, ideoloji, değer gibi unsurlar öne çıkmaktadır." (Akın 2007, s.3). Toffler'in “Üç Dalga” kuramının Bilgi Toplumuna ilişkin olarak literatürde en yaygın kabul gören yaklaşımlardan birisi olduğu söylenebilir. Rossel'e göre (1997, s.30), Bilgi Toplumunu oluşturan temel dinamikler şunlardır:

$\diamond \quad$ Bilgi işleme ve iletişim teknolojilerindeki gelişmeler ve bu teknolojilerin giderek birbiriyle bağlantılı hale gelmesi.

$\diamond \quad$ Daha eğitimli ve bilgili bir nüfusun ortaya çıkması, yönetişim sürecinde güçlü örgütlü grupların gelişmesi.

$\diamond \quad$ Kitle iletişiminin artan rolü ve erişim olanağı.

$\diamond$ İşin yapısını değiştirecek sonuçlar doğuracak daha yüksek uzmanlık gerektiren bilgi temelli bir ekonomi.

$\diamond \quad$ Kamu ve özel kurumlarda gelişen daha zengin bir altyapı ve bu örgütler arasında işbirliği ve içerik açısından daha güçlü bağların oluşması.

Görüldüğü gibi, Bilgi Toplumunun öne çıkan yansımaları bilgi ve iletişim teknolojileri, eğitim ve bilgi ekonomisidir. OECD çerçevesinde yapılan hesaplamalarda Bilgi Ekonomisi olarak nitelendirilen ekonomilerde geniş tanımıyla bilgiye dayalı etkinliklerin payının GSYIH'nın \%40'ını aştığı görülmektedir. Bilgi etkinliklerinin, örneğin, Bilgi Toplumunun bir numaralı adayı olan Amerikan ekonomisi içindeki ağırlığının 1870-1980? tarihleri arasında \%5'den \%50'ye yükseldiği belirtilmektedir. (Işık, 2007, s.82). Daha önce araç olan bilginin Bilgi Toplumunda amaca dönüştüğünden söz edilmektedir. (Külcü, 2001, 
s.4). Bilgi Toplumuna geçişte stratejik kaynak sermaye değil, bilgidir. Zenginlik yaratmak için kullanılan kaynakların hiçbiri bilgi kadar önemli değildir. Yeni ekonomide bilgi ve teknolojinin kişisel üretime uygulanması ekonomik başarının anahtarıdır (Stevenson, 2003, s.11).

Bilgi Toplumu, genel olarak;

$\diamond$ Toplumsal yaşamın her alanında bilginin geçmişle kıyaslanamayacak kadar fazla ve belirleyici biçimde kullanılması;

$\diamond$ Bilginin üretim hızının öncesine göre anlamlı düzeyde yüksek olması;

$\diamond$ Bilgi ekonomisi olarak adlandırılan ekonomik yapıda hizmetler sektörünün tarım ve sanayinin ötesinde bir paya sahip ve hizmet sektörü içinde de bilgiye dayalı etkinliklerin ağırıklı olması;

$\diamond$ Özellikle bilgisayar ve İnternette simgelenen ve bilginin, üretim, depolanma ve erişimini niteliksel olarak farkılısştıran bilgi ve iletişim teknolojilerindeki çok hızlı ve yapısal değişim ile ifade edilebilir.

Kapitalist toplumun yeni bir evresi olarak da değerlendirebileceğimiz bu yapıda bilgi olgusunun belirleyici etkisi temel hareket ve tanımlama noktasıdır.*

Çalışmamız kapsamında üzerinde daha ağırlıkla durulması gereken boyut Bilgi Toplumu-Kütüphane ilişkisidir. Kütüphane kurumunun Bilgi Toplumunun parçası olma nedenini temellendiren bu ilişki noktaları, aynı zamanda kütüphanenin Bilgi Toplumundaki işlevlerine de ışık tutacaktır. Bu bağlamda Bilgi Toplumu-Kütüphane ilişkisinin yoğunlaştığı noktaları şöyle sıralayabiliriz:

$\diamond$ En başta söylenmesi gereken ve kuramsal nitelikli sayılabilecek ilişki; Bilgi Toplumunun bilgi temelli bir toplumsal yapı, kütüphanenin de bilgiyi sağlayan, düzenleyen ve erişime sunan bir kurum olmasından kaynaklanan ilişkidir. Bir başka deyişle, bilgi temelli bir toplumsal yapı ile bilgi üzerine temellenen bir kurum olan kütüphane doğal olarak örtüşmekte, Bilgi Toplumu kütüphane kurumunun varlığını zorunlu kılmaktadır. Kütüphane, Bilgi Toplumunun altyapı koşullarından birisi anlamına gelmektedir. Toplu $(2007$, s.150)'nun da belirttiği gibi, "toplumsal yaşamın bütün alanları bilgi ve onun ürünleri tarafından kuşatııırken" kütüphanelerin bu toplum yapısının merkezinde olmaları zorunludur.

$\diamond$ Yukarıdaki ilişkiyi "bilgi erişim" kavramı üzerinden tartışmak da olanaklıdır. Bilgi Toplumunda temel zorunluluk toplumun ve bireylerin "bilgiye erişimi"dir. Kütüphane kurumunun tarihsel süreçte hiç değişmeyen temel işlevi de "bilgiye eriştirme"dir. Dolayısıyla, BilgiToplumu ve kütüphane kurumu"bilgierişim"olgusu çerçevesinde de örtüşmektedir. Gerçekte, Bilgi Toplumu olgusunun içeriğini

\footnotetext{
* Bilgi Toplumu ile ilgili daha fazla bilgi için Ayr. Bkz. Tonta ve Küçük, 2005.
} 
oluşturan bilgi, bilgi teknolojileri, iletişim, bilgisayar, İnternet vb birçok kavram kütüphane kurumu ile doğrudan ilişkilidir. Dolayısıyla, Bilgi Toplumu-Kütüphane ilişkisini temellendiren kuramsal altyapı oldukça güçlü görünmektedir. Bilginin üretiminden kullanımına kadarki sürecin her aşamasında kütüphane kurumunun var oluşu hem bu temellendirmeye hem de sözü edilen ilişkiye ışı tutar niteliktedir. Kuşkusuz, bilginin sağlanması sadece erişim sorunu açısından değil işlevsellik açısından da önemlidir. Toplu $(1999$, s.335)'ya göre, üretilen bilginin işlevsel hale gelebilmesi bir başka deyişle toplumsal yaşama katkı sağlayabilmesi için elde edilmesine olanak sağlayacak koşulların yaratılması gerekmektedir. Kütüphane, bu koşulları yaratacak başıca kurumlar arasında yer alır. Ayrıca, Bilgi Toplumunda bilginin elektronik ortamda yayımı, iletişim araçları ve oluşturulan ağlar aracılığıyla talep edilen her yerde erişilebilir hale gelmesi yerel ölçekli ve bilgi merkezlerine bağımlı hizmet anlayışını yaratmıştır. (Toplu, 2007, s.160). Bilgi merkezlerine bağımlı bilgi erişim olgusu kütüphaneyi doğal olarak bu erişimi gerçekleştiren kurumlar durumuna getirmiştir.

$\checkmark$ Bilgi Toplumu'nun bilgi teknolojilerine sahip olup olmama anlamında toplumsal bir eşitsizliğe neden olacağı öngörülmektedir. Dünya nüfusunun $\% 10$ 'dan daha az bir kısmının İnternete erişebildiği; İnternete erişebilenlerin \% $85^{\prime}$ inin, internet web sitelerinin yer aldığı alanların \%90'ının da gelişmiş ülkelerde bulunduğu belirtilmektedir (Rao, 2005, s.363). “Dijital Uçurum” (bölünme) olarak adlandırılan ve teknolojiye/teknolojiye erişim olanaklarına sahip olanlarla olmayanların arasındaki farklar biçiminde ifade edilen eşitsizliğin giderilmesinde kütüphaneler sözü edilen teknolojiyi ücretsiz sağlama işleviyle öne çıkmaktadır. Bir başka deyişle, Bilgi Toplumunda kütüphaneler "Dijital Uçurum” un kapatılmasında rol üstlenmektedirler.

$\checkmark$ Günümüz toplumunda ekonomik gücün temelinde bilginin yer aldığına işaret edilmektedir (Fenerci, 2004, s.84). Daha açık bir deyişle, Bilgi Toplumuna geçişte stratejik kaynak sermaye değil, bilgidir. Zenginlik yaratmak için kullanılan kaynakların hiçbiri bilgi kadar önemli değildir. Yeni ekonomide bilgi ve teknolojinin kişisel üretime uygulanması ekonomik başarının anahtarıdır (Stevenson, 2003, s.11). 21. yüzyıla girerken ortaya daha fazla çıkan gerçek, araştırma-geliştirme, yenilenme veya yenilikçilik gibi kavramların kamuoyuna ve ekonomiye mal edilememesi durumunda ekonomik gelişmelerin önümüzdeki yıllarda tekrar tökezleme noktasına geleceği, daha da önemlisi, hızla artan nüfusla baş edilemeyecek olunmasıdır (Eczacıbaşı, 2006, s.204). Bir başka açıdan bakıldığında, verimliliği artırmak, nitelikli istihdam yaratmak, istikrarlı büyüme sağlamak, ulusal rekabet avantajı elde etmek ve kalkınmayı sürdürülebilir kılmak, bilgi ve iletişim teknolojilerini kullanmaktan ve bilgi ekonomisini yerleştirmekten geçiyor. Ulusal bilgi politikasının hedeflemesi gereken "ulusal fayda", bilgiyi üretmek, işlemek, paylaşmak ve yönetmeye, yani küresel oyuncu olmaya bağlıdır (Uçkan, 2006). Kısaca, yukarıda sıralanan gelişmeleri içeren ve 
küresel oyuncu olmayı sağlayacak Bilgi Ekonomisi olarak adlandırılan ekonomik yapının kurulmasında da bilgiye eriştiren kurumlar olarak kütüphaneler ciddi sorumluluklar üstlenmektedirler.

$\checkmark$ Bilgi Toplumu için altyapısal koşullardan ve aynı zamanda "Dijital Uçurum"un azaltılmasındaki koşullardan birisi de bireylerin bilgiye erişimlerini sağlayacak bilgi ve beceriyi kazandıracak eğitimdir. Kütüphane kurumu, toplumun Bilgi Toplumuna uyumu konusunda gerekli eğitimi ücretsiz sağlayarak katkıda bulunmaktadır.

$\diamond$ Bilgi Toplumunun toplumsal boyutu sayılan "küreselleşme" olgusu ile kültürün tekleşmesi ve yerel kültürel mirasların yok olması tehlikesi yerel kültür mirası ürünlerinin korunmasını ve evrensel düzeyde paylaşımını/erişimini zorunlu bir gereksinim olarak gündeme getirmiştir. Kütüphaneler, yerel kültürel mirasın dijitalleştirilerek korunması ve erişime açılmasında doğrudan işlev yüklenirler ve Bilgi Toplumunun parçası olurlar.

$\diamond$ Bilgi Toplumu-kütüphane ilişkisinin ortaya çıktığı noktalardan birisi de kütüphanecinin değişen işlevinde görülmektedir. Toplu (2007, s.156), Bilgi Toplumunda kütüphanecinin işlevinin ve hatta kimliğinin değiştiğini ve bu çerçevede onun artık bilgi kaynaklarının tanımlanması yanında bilginin içeriği ile ilgilenmek ve bilgi kaynaklarının yanında bizzat bilginin kendisini yönetmekle sorumlu olduğunu belirtmektedir. Bu çerçevede kütüphaneci veri tabanlarının oluşturulmasından bilgi sistemlerinin tasarımına kadar yeni sorumluluklar yüklenmeye başlamıştır.

$\diamond$ Bilgi Toplumunda bilgi artış hızı ile gündeme gelen geneldeki bilgi kirliliği, güvenilir, doğru, nitelikli bilgi edinme konuları ile elektronik ortamdaki veri ve bilgilerin güvenliği konusu da büyük önem taşımaktadır. Kütüphaneler, sözü edilen konularda ortaya çıkan sorunların çözümüne doğrudan katkı sağlayan kurumlardır. Fenerci (2004, s.90) Bilgi Toplumunda evrensel ilkenin herkesin hem bilgi teknolojilerine hem de bilgiye erişimde fırsat eşitliğine sahip olması olduğunu dile getirirken, bu erişim eşitliğine sahip olmak kadar hangi bilgiye erişildiğinin de büyük önem taşıdığına dikkat çekmektedir. Bu bağlamda, bilginin kapsam, düzey, dil ve içerik açısından insanların gereksinimlerini karşılayabilecek nitelikte olması gerekir. Kütüphaneler bu açıdan da işlev yüklenecek başlıca kuruluşlardır.

$\diamond$ Bilgi Toplumunun öne çıkardığı konulardan birisi de düşünce özgürlüğü ve telif haklarıdır. Kütüphaneler bu konularda rol üstlenen, sağladığı bilgi kaynaklarıyla fikir ve düşüncelerin telif haklarına uygun olarak yayılmasına aracilık eden kuruluşlardır.

$\checkmark \quad$ Bilgi Toplumu demokratik niteliği daha yüksek bir toplumdur. İyi geliştirilmiş bir bilgi altyapısı bilginin serbestçe dolaşımını ve böylece toplumun karar verme 
süreçlerine daha bilinçli biçimde katılımını sağlayarak demokratikleşmeye katkıda bulunulacak ve demokrasi dışı baskıları da engelleyebilecektir (Toplu, 2007, s.161). Kütüphane bilginin dolaşımında, dolayısıyla Bilgi Toplumunun gerektirdiği demokratikleşmede rol alan temel kuruluş arasında yer alır.

2003 yılında Genova ve 2005 yılında da Tunus'ta düzenlenen Dünya Bilgi Toplumu Zirvesi (WSIS-World Summit on the Information Society)'nde yayımlanan ve 11 başlıktan oluşan Eylem Planı'na dayalı olarak IFLA'nın hazırladığı "Kütüphaneler ve Dünya Bilgi Toplumu Zirvesi" adlı raporda kütüphanelerle Bilgi Toplumu ilişkisinin, belirlenen 11 eylemin tümünde söz konusu olduğu söylenebilir (IFLA, 2010). Bu Plan'da ve dolayısıyla IFLA'nın raporunda Bilgi Toplumu-kütüphaneler ilişkisinin belirginleştiği noktalar şöylece özetlenebilir:

$\diamond \quad$ Kütüphaneler, Bilgi Toplumu için var olan bir ağ ve temel kaynaktır.

$\diamond \quad$ Kütüphaneler, bilgi kullanıcısına yakındır ve dünyanın çoğu yerinde kolaylıkla ulaşılabilir kurumlardır.

$\diamond$ Kütüphaneler, bilgi kaynaklarının içeriğinin değerlendirilmesinde uzmanlaşmış kurumlardır.

$\diamond \quad$ Bilgi Toplumunun tüm olanaklarından yararlanabilmek için herkesin gerekli becerilere ve Bilgi ve İletişim Teknolojileri (BiT) okuryazarlığına sahip olması gerekir. Kütüphaneler bu becerilerin özellikle eğitimli olmayan, çalışmayan bireylere kazandırılmasında çok önemli kurumlardır. Bir başka deyişle, kütüphaneler, e-okuryazarlık anlamına gelen bilgi ve iletişim teknolojileri kullanım becerileri için özel eğitim programları da düzenleyen yerel eğitim ve yetiştirme merkezleridir.

$\diamond \quad$ Kütüphaneler, BiT konusunda uzaktan eğitim gibi programlarının parçası olarak da destek verici kurumlardır.

$\diamond$ Kütüphaneler, eğitim-araştırma kurumları ile bağlantılı ve ağ tabanlı BiT'lerin tasarlanmasını hedefleyen pilot projelerde de işlev yüklenir.

$\diamond$ Kütüphaneler, olumlu İnternet kullanım modellerinin geliştirilmesinde rol oynayabilirler. Bu çerçevede, onlar, gereksinim duyulan bilgiyi sağlarlar. Bunun da ötesinde, kütüphaneler, web tabanlı farklı ve geniş bir materyal çeşitliliği sunar.

$\diamond$ Kütüphaneler, ulusal, bölgesel ve yerel Bilgi Toplumu politikalarının yaşama geçirilmesinde yerel toplulukların temel İnternet erişim merkezleri olarak yer alır.

$\diamond \quad$ Kütüphaneler, basılı ve elektronik bilgi ve belgelerin depolanması ve arşivlenmesi için çeşitli uygulama ve çalışmalar yapar. Kültürel mirasın korunmasında ulusal kütüphane ve arşivlerin uzun süreli deneyimleri Bilgi Toplumu amacının başarılmasında çok önemlidir. 
IFLA'nın Bilgi Toplumu-kütüphaneler ilişkisi açısından altını çizdiği noktaların, daha öncesıralanan maddelerde de dikkatçekildiğiüzere, özellikle BiT'in toplumsallaştırılması/ yaygınlaştırılması, bu konuda toplumsal kapasite yaratma ve bilgiye erişim ile ilgili olduğu görülmektedir.

Yukarıda sıralanan bütün ilişki konularına dayanarak Bilgi Toplumu-kütüphane ilişkisi üzerine şu genel çıkarımda bulunmak olanaklıdır: "Kütüphane, Bilgi Toplumunun temel kurumlarından birisidir."

Bu çalışmada "strateji" ile eş anlamda kullanılan, politika terimi; genelde "Belirlenen amaç veya hedeflere ulaşmaya yönelik karar ve eylemler bütünü" biçiminde tanımlanmaktadır (Türk Dil Kurumu, 2010). De Beer (2005, s.53)'e göre ise, politika; "belirli toplumlar içinde sorumlu karar alıcılar tarafından geliştirilen, belirli bir amacı ve hedefi olan bir program ve ifadeler demetidir." Kısaca, politika kavramının; "belirlenen amaçlara/hedeflere ulaşmak için izlenecek ve plan, program ve projeler gibi unsurlardan oluşan yol, yöntem" anlamına geldiği söylenebilir. Tanıma dayanarak, politika ya da strateji kavramının "hedefler" ve "yol-yöntem" olmak üzere iki ana parçadan oluştuğu anlaşılmaktadır. "Hedefler koyma" ve bu hedefler ulaşmayı sağlayacak "yöntem belirleme" anlamıyla politika olgusunun bir ülkede toplumsal yaşamın her parçası için söz konusu olduğu öne sürülebilir. Ticaret politikası, kadın politikası, eğitim politikası, enerji politikası, sanat politikası gibi politikalar ilgili alanlarda doğal olarak "hedefleryöntem" ilişkisini ifade eder.

Yukarıdaki sunulan kavramsal çerçevede bakıldığında, bir toplumsal değişim süreci olarak Bilgi Toplumuna ilişkin olarak da bir politikadan söz edilebileceği açıktır. Bu sürecin, konulan hedefler doğrultusunda başarıya ulaştırılması için belirlenen yol, yöntem anlamıyla Bilgi Toplumu Politikasına kaynaklık eden temel kavram ise bilgi politikasıdır.

Dünyada başlangıcı ABD'de Weinberg tarafından hazırlanan Rapora (1963) dayandırılan bilgi politikasını Weingarten (1996, s.45); "bilginin yaratılması, kullanımı, depolanması ve iletimi ile ilgili bütün kamu yasaları, düzenlemeler ve politikalar" biçiminde tanımlamaktadır. Daha kapsayıcı ve evrensel bir yaklaşımla, Montviloff $(1990$, s.7) kurumsal, ulusal, bölgesel ve uluslararası düzeyde formüle edilebileceğini belirttiği bilgi politikası kavramını, "bilgi kaynaklarının, hizmetlerinin ve sistemlerinin geliştirilmesi ve kullanılması için tasarlanacak strateji ve programlara rehberlik edecek politika" biçiminde tanımlar. Kanımızca, ulusal düzeyde bir bilgi politikası; "bir ülkedeki bütün bireylerin gereksinim duydukları bilgiye erişimlerini sağlayacak plan, program ve proje gibi unsurların oluşturduğu yol, yöntem" olarak tanımlanabilir. Kuşkusuz, tanımda "bilgiye erişim" olarak dile getirilen hedef, bilginin kullanımı ve bu kullanım ile bireyin/toplumun dönüşümünün sağlanması olgularını da kapsamaktadır. Elbette, bilgi politikasının, günümüzde Bilgi Toplumu stratejisi/politikası olduğu, yani aynı anlama geldiği de en azından bu çalışma için gözden kaçırımamalıdır. 
Yukarıda, Bilgi Toplumu-kütüphane ilişkisine yönelik olarak yapılan belirlemelere dayanarak, "kütüphanenin Bilgi Toplumunun temel kurumlarından birisi olduğu” ortaya konulmuştu. Bilgi üzerine temellenen bir kurum ile adını bilgiden alan bir toplum yapısının örtüştüğü en azından kuramsal olarak açıktır. Bilgi politikasına ilişkin olarak yapılan çeşitli tanımlar bu örtüşmeyi biraz daha ayrıntılı biçime dönüştürmektedir. Duff (2004), yaptığı bilgi politikası tanımında kapsama bilgi özgürlüğü, kişisel hakların dokunulmazlığı, veri koruma ve güvenliği, telif hakları ve entelektüel mülkiyet, enformasyon altyapısı ve enformasyon akışı gibi kavramların yanı sıra kütüphaneler ve arşivleri de almıştır. Yine bir çalışmada, Toplu (2007, ss.132-134) bilgi politikası tanımlarını sıraladıktan sonra yeni bilgi politikası tanım ve oluşturma süreçlerinde bilgi merkezi ve bilgi hizmeti odaklıyaklaşımların ağırlığını artırdığına dikkat çekmektedir. Rehman (1996, s.187) bilgi politikasının olması gereken bileşenlerini sayarken, "bilgi kuruluşlarının rol ve katkılarını da" bu kapsama dâhil etmektedir. Daha açıkçası, kütüphaneler ve diğer bilgi merkezleri de dâhil olmak üzere, bilgi ile ilgili her kuruluş bütün alt yapı unsurları, üst yapıyı oluşturan tüm hizmetleri ile ulusal bilgi politikasının kapsamı içinde olmak durumundadır (Alkan, 1997, s.242). Montviloff (1990, s.6) ulusal bilgi politikalarının dört ana unsura dayandığından söz ederken, bunları; 1. Bilgi kaynakları, 2. Bilgi hizmetleri, 3. Bilgi sistemleri, 4. Bilgi altyapısı olarak sıralar ve kütüphane ve arşiv gibi bilgi merkezlerini "Bilgi hizmetleri" unsurunun içinde yer alan kurumlar olarak kabul eder.

Kısaca, daha birçok gerekçe bulunabilir; ancak gerek yapılan tanımlamalar gerekse bilgi politikasının kapsamına yönelik kuramsal yaklaşımlar bilgi politikalarının kütüphane kurumunu zorunlu olarak içermesi gereken politikalar olduğunu açıkça ortaya koymaktadır. Bu nokta bize bir sonraki bölümde "Türkiye'nin bilgi politikasının kütüphane kurumunu hangi düzeyde ve nitelikte içerdiğine" yönelik yapacağımız değerlendirme için kuramsal bir zemin oluşturmaktadır. Diğer bir deyişle, kuramsal olarak dile getirilen "bir ülkenin bilgi politikası kütüphane kurumunu o politikanın bir parçası/bileşeni olarak kabul etmelidir" sayıtlısı, Türkiye'ye yönelik bu konuda yapılacak bir çözümleme için hareket noktası niteliği taşımaktadır.

\section{Türkiye'nin Bilgi Toplumu Politikasında Kütüphane Kurumuna Yaklaşım}

Daha önceki tanımlara ve kuramsal yaklaşıma dayanarak, Bilgi Toplumu Politikasını; "Bir ülkenin Bilgi Toplumu olabilmesi ve bu nitelikteki varlığını geliştirip sürdürebilmesi için belirlediği hedeflere ulaşmada izleyeceği yol, yöntem" olarak tanımlayabiliriz. Kuşkusuz, bir ülkenin Bilgi Toplumu politikasının irdelenmesinde o ülkede bilim, teknoloji, eğitim, iletişim vb. birçok alanda hazırlanmış resmi rapor, belge vb. ile çıkarılmış tüm yasa, yönetmelik, kararname, hükümet programı, kalkınma planları, resmi şura kararları gibi yasal belgelerin söz konusu olacağı söylenebilir. Kabul edileceği üzere, bunun bir makale sınırlılığında yapılması olanaklı değildir. Bu çalışmada, Türkiye'de her alanda hükümetler için temel politika üreticisi olan Devlet Planlama Teşkilatı'nın 
(DPT) doğrudan ele aldığımız konuya yönelik olarak hazırladığı belgeler temelinde bir değerlendirme yapılacaktır. Bu kapsamda bir değerlendirme, kendisi içermese de, özellikle TÜBiTAK'ın konuyla ilgili hazırladığı bazı önemli raporların (TÜBITAK, 1983, 1993) göz ardı edilmemesi gerektiğine de dikkat çekmek durumundadır.

Türkiye'nin Bilgi Toplumu Politikasında kütüphane kurumuna yaklaşımın değerlendirilmesine geçmeden önce, onun, Bilgi Toplumu aşamasına ne kadar yakın ya da uzak olduğuna bakmak fotoğrafı görmek açısından yararlı olacaktır. Dünya Ekonomik Formu tarafından hazırlanan ve 2008-2009 yılları itibariyle Türkiye'nin Bilgi Toplumuna hazır oluş durumunu sayısal olarak diğer ülkeler sıralamasıyla veren tablo (Tablo I) aşağıdadır.

Tablo I. Ülkelerin Bilgi Toplumuna Hazır Olma Durumu (2008)

\begin{tabular}{clc}
\hline Sıra No & Ülkeler* & Puan \\
\hline 1 & Danimarka & 5.85 \\
2 & ABD & 5.84 \\
3 & İsveç & 5.68 \\
4 & İsviçre & 5.67 \\
5 & Singapur & 5.58 \\
6 & İsviçre & 5.53 \\
7 & Finlandiya & 5.50 \\
8 & İzlanda & 5.49 \\
9 & G. Kore & 5.48 \\
10 & Norveç & 5.41 \\
$\ldots$ & $\ldots$ & $\ldots$ \\
$\mathbf{5 5}$ & Türkiye & 3.91 \\
\hline
\end{tabular}

*Toplam ülke sayısı134.

Kaynak: Dünya Ekonomi Forumu (Bilgi Toplumu, 2010)

Teknik altyapı göstergeleri kadar, ülkelerin hizmetlerin sunumu ve geliştirilmesindeki durumu, teknoloji üretme yetenekleri, insan sermayesi, hukuksal düzenlemeleri gibi birçok ölçüt kullanılarak hazırlanan "Küresel Bilgi Teknolojisi" adlı rapordan alınan bu bilgilerle oluşturulanTablo'da ilk 10 ülke ile Türkiye yer almaktadır. Toplam ülke sayısının 134 olduğu göz önüne alındığında Türkiye'nin 55. sırada oluşu "orta" olarak değerlendirilebilir. Aynı Raporda Türkiye'nin sırasının 61'e gerilediği de görülmektedir. Bunun dışında, "Türkiye'de 2003 yılında 10,3 milyar dolar seviyesinde olan BiT pazarı, yıllık ortalama yüzde 18 büyüyerek 2008 yılında 23,8 milyar dolara ulaşmıştır. Sektör büyüklügünün 2009 yılında 21,8 milyar dolara gerileyeceği tahmin edilmektedir. Sektörün yüzde $70^{\prime}$ lik kısmını telekomünikasyon sektörü, yüzde 30'luk kısmını da bilgi teknolojileri sektörünün oluşturduğu değerlendirilmektedir. Sabit telefon sayısı 
doyuma ulaşmış olmasına karşın mobil telefon abone sayısında artış sürmektedir. Genişbant abone sayısında oldukça hızlı bir büyüme yaşanmaktadır. Ancak, ulaşılan abone yoğunluk oranı henüz $A B$ ve OECD ortalamalarının oldukça altında kalmaktadır" (Bilgi Toplumu, 2010).

Kuşkusuz, Türkiye'de Bilgi Toplumunu gerçekleştirme adına olumlu olarak değerlendirilmesi gereken en önemli gelişmenin, e-Dönüşüm Türkiye Projesi'nin eşgüdümünü sağlamak, kamu kurumlarının bilgi ve iletişim teknolojisi yatırımları arasında eşgüdüm kurmak ve Bilgi Toplumu olma yolunda atılması gereken adımlara ilişkin stratejileri belirlemek üzere 2003 yılı Mart ayında Başbakanlık Devlet Planlama Teşkilatı içinde Bilgi Toplumu Dairesi adıyla bir planlama biriminin kurulması olduğu söylenebilir.

Çalışmamızın daha önce sözü edilen sınırlılığından dolayı DPT'nin hazırladığı iki temel strateji/politika belgesi ile bunlara bağlı alt belgeler irdelenecektir. Bugün, Türkiye'de Bilgi ToplumuPolitikası ile doğrudan ilgili ve üstelik devletin merkezi planlama örgütü tarafından hazırlanmış ve çalışmamızdaki değerlendirmelere konu edeceğimiz temel belgeler;

1. e-Türkiye Girişimi Eylem Planı-2002

2. e-Dönüşüm Türkiye Projesi Kısa Dönem Eylem Planı (2003-2004)

3. e-Dönüşüm Türkiye Projesi 2005 Eylem Planı

4. Bilgi Toplumu Stratejisi 2006-2010

5. Bilgi Toplumu Stratejisi 2006-2010: Eylem Planı'dır (Bilgi Toplumu, 2010).

Bunların yanı sıra yayımlanan "Bilgi Toplumu Stratejisi Değerlendirme Raporları" (Bilgi Toplumu, 2010) da konu ile ilgili altbelgeler olarak ele alınacaktır. Değerlendirmeyi, belgelerin hazırlanma ve uygulanmasındaki tarihsel sıraya göre yapmak uygun olacaktır.

Kuşkusuz, Türkiye'de Bilgi Toplumu Politikasına yönelik çabalar arasında burada ele alınmayan Bilişim ve Ekonomik Modernizasyon Raporu, Türkiye Ulusal Enformasyon Altyapısı Anaplanı (TUENA), e-Ticaret Koordinasyon Kurulu (1998-2002) ve KamuNET (1998-2002) gibi plan, rapor ve girişimler bulunmaktadır (Bilgi Toplumu, 2010).

Sözü edilen belgelerin incelenmesi, Türkiye'de bilgi politikası bağlamında kütüphane kurumuna ilişkin olarak geliştirilen yaklaşıma belirli ölçüde ışık tutacak, bu konuda önemli ipuçları verebilecektir. 


\section{1. e-Türkiye Girişimi Eylem Planı'nda Kütüphane Kurumuna Yaklaşım}

Ağırlıkla, Türkiye Bilişim Derneği tarafından DPT ile işbirliği içinde e-Avrupa+ girişiminin Türkiye türevi olarak değerlendirilerek başlatılan e-Türkiye çalışmalarının amacında, e-Türkiye Girişimi Eylem Planı'nın; Türkiye'de bilgi toplumuna temel yapı taşlarının oluşumunun hızlandırılması, daha ucuz, hızlı ve güvenli internet erişimi, insan kaynağına yatırım ve internet kullanımının yaygınlaştırılması hedeflerine ulaşabilmek için, eEğitim, e-Devlet, e-Ticaret, e-Çevre, e-Sağlık ve benzeri konular olmak üzere birçok alt bileşende ele alınan Türkiye'nin bilgi toplumu çalışmaları için taban oluşturacağı ve yol göstereceği belirtilmektedir (T.C. Başbakanlık, 2002a). Planda, "Türkiye'de bilgi toplumuna temel yapı taşlarının oluşumu" başlığında sıralanan "İnternet Kullanımının Yaygınlaştırılması" maddesi altında e-arşiv ve e-kütüphane paragrafı yer almakta ve sözü edilen yerde "Arşiv ve kütüphane hizmetlerinin elektronik ortamda yürütülmesi ve resmi yazışmalarda standartların oluşturulması" ifadesi yer almaktadır. Türkiye'de Bilgi Toplumu Politikası için bir anlamda ciddi girişimlerin hazırlık aşaması olarak değerlendirilebilecek böyle bir belgede bu ifadenin bulunması, "kütüphane kurumunun başlangıçta Bilgi Toplumu Politikasının bir parçası biçiminde görüldüğünü" ortaya koyması açısından önem taşımaktadır. Sözü edilen Plan'da e-Arşiv ve e-Kütüphanenin "Türkiye'de bilgi toplumuna temel yapı taşlarının oluşumu"nda, dolayısıyla Bilgi Toplumu Stratejisinin içinde yer alan bir unsur olarak görülmesinin gerekçesi şöyle belirlenmiştir:

"Arşivler, devletlerin ve milletlerin haklarını ve uluslararası ilişkileri belgeler, korur ve milletlerin hafızası olması sebebiyle de geleceğe yön verirler. Arşiv hizmetlerinin elektronik ortamda yürütülmesi hem kurum ve kuruluşların hizmetlerini daha etkin ve kolay yürütmesini, hem de vatandaşların devlet hizmetlerinden daha hızlı ve kolay bir şekilde yararlanmasını ve bürokratik işlemlerin de azalması anlamına gelir.

Toplumsal birer kurum olan kütüphaneler, ait oldukları toplumun bilgi ihtiyacını karşılayabildikleri oranda varlıklarını devam ettirebilmektedirler. İçinde yaşadığımız süreçte, bilginin her zamankinden daha fazla önem kazanması, bilginin şu anda ekonomide bir üretim faktörü olarak kabul edilmesi, güncel bilgilere daha hızı ve kolay erişimin gerekliliği bilgi kaynaklarındaki büyük artış ve formatlarının çeşitlenmesi ve teknolojik alandaki gelişmelerle birlikte, ihtiyaç duyulan her türlü bilgiyi sağlamayı amaç edinen kütüphaneler; ülke olarak bilgi çağını yakalama ve bilgi toplumu olma yolunda önemli bir işlev yüklenmişlerdir.

Dolayısıyla yeni yüzyılda bilişim ve teknolojideki hızlı değişim ile birlikte, arşivlerin ve kütüphanelerin de yenilenmeleri, fonksiyonlarını ve hizmetlerini bu değişim doğrultusunda sürdürmeleri gerekmektedir. Ayrıca, e-Avrupa+ girişimine uygun olarak Türkiye'deki e-Türkiye girişiminde arşivler ve kütüphaneler bilgi toplumunu yakalama yolunda en önemli kurumlar arasında yer almaktadır." (T.C. Başbakanlık, 2002a). 
Gerekçe'de arşiv ve kütüphane kurumunun Bilgi Toplumundaki işlevleri genelde doğru biçimde belirlenmiş, bu toplumsal değişim sürecinde kendilerini neden yenilemeleri gerektiği ortaya konmuş ve Bilgi Toplumunu yakalama yolundaki önemleri vurgulanmıştır. Son derece olumlu sayılabilecek bu yaklaşımın kanımızca eleştirilebilecek en önemli yanı "sorunu sadece elektronik boyutla sınırlı tutmuş" olmasıdır. e-Dönüşüm kavramı çerçevesinde bakıldığında anlaşılır bir durum olmakla birlikte, sorunun arşiv-kütüphane kaynak ve hizmetlerinin elektronik ortama taşınması dışında değerlendirilmesi, gereken eğitim-kültür politika ve uygulamaları gibi yanlarının da olduğu gözden kaçırılmamalıdır.

e-Arşiv ve e-Kütüphane maddesinin kapsamı “Kamu kurum ve kuruluşlarındaki tüm arşivler, kütüphaneler, dokümantasyon, araştırma ve bilgi merkezleri" olarak belirtilmiş; amaç ve hedefler de "Arşiv ve kütüphane hizmetlerinin elektronik ortamda yürütülmesi" biçiminde ortaya konmuştur. Bu kapsam ve amaç-hedefler çerçevesinde yapılması gereken işler ise şöyle sıralanmıştır:

1. "Standard dosyalama ve haberleşme kodlarının belirlenerek tüm resmiyazışmalarda birliktelik sağlamak,

2. Tarihi arşivlerden tasnifi tamamlanan belge serilerini elektronik ortamda araştırmaya açmak,

3. Elektronik ortamlarda oluşturulan ve oluşturulacak olan arşiv malzemelerinin standartlarını belirlemek ve yapılacak çalışmalar sonucu elektronik belge rehberini hazırlamak,

4. Kütüphaneler ve bilgi merkezlerindeki materyalin bibliyografik kayıtları ile seçilmiş önemli materyallerin içeriğini elektronik ortama aktarmak ve internetten hizmete açmak,

5. Yazma eserlere ait bibliyografik kayıtlar ile tam metin kayıtlarını elektronik ortama aktarmak ve internetten hizmete sunmak" (T.C. Başbakanlık, 2002a).

Yukarıda değerlendirilen Gerekçe'de kütüphaneye ilişkin benzer bir yaklaşımın "Yapılacak İşler" bölümünde de var olduğu görülmektedir. Kaynak ve hizmetlerin elektronik ortama aktarılarak, erişime açılması beklenen temel görev/iş olarak öne çıkmaktadır. Başında "e" olan bir projede bu işin öne çıkması doğaldır. Ancak, daha önce de belirtildiği üzere Bilgi Toplumu ekonomik, toplumsal, kültürel ve eğitim gibi boyutları olan çok yönlü bir değişim sürecidir ve kütüphanelerin bu süreçteki işlevleri " $e$ " ile sınırlanamaz. Böyle bir politikada kütüphane kurumuna daha geniş bir açıdan bakılması beklenir. Örneğin; bu Plan'da yer alan ana bölümlerden “İnsan kaynağına yatırım” başlığı altında "Eğitim ve Insan Kaynakları", "Ülkenin sayısal çağa hazırlanması; Bilgi tabanlı ekonomide iş gücü oluşturulması; Bilgi tabanlı ekonomiye herkesin katılımının sağlanması" gibi alt başlıklar bulunmaktadır. Sözü edilen bu bölümlerde kütüphane kurumuna 
ilişkin bir değerlendirme yer almamaktadır. Oysa anılan başlıkların tümünün içeriğinde kütüphanenin bulunması gerekir. Örneğin, "Ülkenin sayısal çağa hazırlanması"nda gerekli olan eğitim altyapısını verecek kuruluşlar arasında kütüphaneler zorunlu olarak yer almak durumundadır. Dolayısıyla, kütüphanelerin Bilgi Toplumu Politikasındaki işlevlerini "e" ile sınırlamak bir "işlev sınırlaması" olarak değerlendirilebilir. Benzer biçimde, Plan'da "Internet kullanımının yaygınlaştıııması" bölümünün e-Ticaret, eDevlet, e-Sağlık, e-Çevre gibi parçalarında da katkı sağlayabileceği halde kütüphane kurumuna bir gönderme yapılmamıştır.

Plan'la ilgili 2002 Mayıs tarihinde hazırlanan e-Türkiye Girişimi I. Ara Raporu'nda (T.C. Başbakanlık, 2002b) arşiv ve kütüphaneler ile ilgili yaklaşımın daha güçlü, doyurucu ve kapsayıcı olduğu da dikkat çekmektedir. Başbakanlık Devlet Arşivleri Genel Müdürlüğünün etkisiyle ortaya çıktığı anlaşılan bu tablo, politika belirlemede kütüphanecilerin ve kütüphanelerin duyarlılık ve çabalarının ne kadar önemli olabileceğini de göstermektedir.

Sonuç olarak, bu Plan'ın kütüphaneye yönelik yaklaşım açısından başlangıç belgesi olması itibariyle taşıdığı önem de dikkate alınırsa "tam istenen ölçüde olmamakla birlikte olumlu bir içerik taşıdığı" söylenebilir.

\section{2. e-Dönüşüm Türkiye Projesi 2003-2004 Kısa Dönem Eylem Planı ve 2005 Eylem Planı’nda Kütüphane Kurumuna Yaklaşım}

2003/12 Sayılı Başbakanlık Genelgesi'nde, e-Dönüşüm Türkiye Projesi'nin başlıca hedefi; "vatandaşlarımıza daha kaliteli ve hızlı kamu hizmeti sunabilmek amacıyla; katılımcı, şeffaf, etkin ve basit iş süreçlerine sahip olmayı ilke edinmiş bir devlet yapısı oluşturacak koşulların hazırlanması" biçiminde belirtilmiştir (Bilgi Toplumu, 2010). Bu Projenin amaçları arasında gerçekleştirilmesinde kütüphanelerin rol alabileceği şu maddeler dikkat çekmektedir.

$\diamond$ Vatandaşın, bilgi ve iletişim teknolojileri yardımıyla, kamusal alandaki karar alma süreçlerine katılımını sağlayacak mekanizmaların geliştirilmesi,

$\diamond$ Bilgi ve iletişim teknolojilerinin kullanımının yaygınlaştırılması,

Bilgi ve iletişim teknolojilerinin vatandaşlar tarafından en yaygın biçimde kullanılmasının sağlanması doğal olarak bu konuda bir eğitim gereksinimini ortaya çıkarmaktadır. Bu eğitimin özellikle ücretsiz olarak verilmesinde kütüphaneler (özellikle halk kütüphaneleri) rahatlıkla katkı sunabilir ve zaten çeşitli ülkelerde de sunmaktadır. Ayrıca, eğitimini almış olsalar dahi vatandaşların tümünün bu teknolojik olanaklara sahip olacakları düşünülemez. Kütüphaneler bu noktada devreye giren ve bu olanağı vatandaşlara ücretsiz olarak sağlayan kurumlardır. Ancak sözü edilen Projenin amaçlarının açıklanmasında kütüphane kurumunun adı geçmemektedir. 
Belirlenen amaçların gerçekleştirilmesi için bu Proje kapsamında 8 Çalışma Grubu, eDönüşüm Türkiye İcra Kurulu ve e-Dönüşüm Türkiye Danışma Kurulu adıyla çeşitli kurullar oluşturulmuştur. İncelendiğinde, çalışma grupları içinde kütüphanelerle dolaylı olarak ilgili sayılabilecek sadece Milli Eğitim Bakanlığı görülmektedir. Çeşitli üniversitelerin Bilgisayar Mühendisliği bölümlerinden öğretim üyeleri, bilgi işlem daire başkanlıkları yetkilileri ve Ankara, İzmir, Çorum gibi bazı belediye temsilcilerinin bulunduğu ve 2008 yılı içinde 2 toplantı yapan e-Dönüşüm Türkiye İcra Kurulu'nda (Dönüşüm Liderleri Kurulu) herhangi bir kütüphaneci yer almamaktadır. Buna karşın, 25 üyeden oluşan e-Dönüşüm Türkiye Danışma Kurulu'nda Türk Kütüphaneciler Derneği ile Üniversite ve Araştırma Kütüphanecileri Derneği de bulunmaktadır. Kurul, yalnızca 2008 tarihinde bir toplantı yapmış ve bu toplantıda her iki mesleki dernekten de birer katılımcı yer almıştır.

Sözü edilen çalışma grupları ve kurullara bakarak Bilgi Toplumu Politikasının örgütlenme alt yapısında kütüphane ve kütüphaneciye "sınırlı" bir yer verildiği söylenebilir. e-Dönüşüm Türkiye Danışma Kurulu'na göre daha güçlü bir yaptırım kapasitesi olan ve 2 temsilciyle Yüksek Öğrenim Kredi ve Yurtlar Kurumu, 4 temsilciyle Çorum Belediyesi Bilgi İşlem Müdürlüğü gibi kurumların yer aldığı e-Dönüşüm Türkiye İcra Kurulu'nda, örneğin Milli Kütüphane gibi bir kütüphanenin bulunmaması Bilgi Toplumu Politikasında kütüphaneye bakışı da yansıtan bir olumsuzluk ve eksiklik olarak değerlendirilebilir.

Türkiye'de Bilgi Toplumu Politikasının oluşturulması ve uygulanması için gerekli örgütsel altyapıya ilişkin kütüphane ve kütüphaneci algısını kısaca değerlendirdikten sonra bu sürecin başlangıcında yer alan belgelerden sayabileceğimiz "e-Dönüşüm Türkiye Projesi Kısa Dönem Eylem Planı (2003-2004)"ile e-Dönüşüm Türkiye Projesi 2005 Eylem Planı'na bakılabilir.

e-Dönüşüm Türkiye Projesi kapsamında oluşturulan çalışma gruplarının yaptığı çalışmalar sonunda ortaya çıkan ve 4.12.2003 tarihinde yayımlanan 2003/48 sayılı Başbakanlık Genelgesiyle uygulamaya konulan e-Dönüşüm Türkiye Projesi Kısa Dönem Eylem Planı; 8 ana başlık altında (Bilgi Toplumu Stratejisi,Teknik Altyapı ve Bilgi Güvenliği, Eğitim ve İnsan Kaynakları, Hukuki Altyapı, Standartlar, e-Devlet, e-Sağlık, e-Ticaret) 73 eylemin 2004 yılı sonuna kadar tamamlanmasını öngörmüştür. KDEP, daha önce eTürkiye Girişiminde kısmen öngörülen, ancak hayata geçirilemeyen eylemleri de belli bir sistematik içinde ele alarak hayata geçirmeyi ve e-dönüşümün altyapı sorunlarını çözmeyi hedeflemiştir (Devlet Planlama Teşkilatı, DPT, 2005a).

e-Dönüşüm Türkiye Projesi'ni gerçekleştirme ve buna bağlı olarak Bilgi Toplumu Stratejisi oluşturma amacı ile hazırlanan Kısa Dönem Eylem Planı'nda Bilgi Toplumu Stratejisi başlığı altında"Teknik Altyapı ve Bilgi Güvenliği, Eğitim ve İnsan Kaynakları, Hukuki Altyapı, Standartlar, e-Devlet, e-Sağlık, e-Ticaret" gibi alt başlıklar ve bu konularda yapılması planlanan toplam 73 tane eylem yer almaktadır. Plan incelendiğinde kütüphane konusundaki yaklaşımın son derece yetersiz olduğunu söyleyebiliriz. Yapılması planlanan 73 eylemden yalnızca elli iki'si arşivlerle ilgili görünmektedir. Sözü 
edilen bu eylem "Tarihi arşivlerdeki tasnifi tamamlanan belgelere ait katalog bilgileri ile görüntülerinin elektronik ortamda hizmete sunulması"dır (Bilgi Toplumu, 2010). Devlet Arşivleri Genel Müdürlüğüne bağlı Osmanlı Arşivi ve Cumhuriyet Arşivi'nde işlemleri tamamlanan yaklaşık 1 milyon belgeye ait katalog bilgilerinin Nisan 2002'den itibaren www.devletarsivleri.gov.tr adresinden araştırmaya açıldığı dile getirilen eylem açıklamasında, 2003-2004yıllarında belge görüntülerinin de elektronik ortamda hizmete sunulmasının amaçlandığı belirtilmektedir. Plan'da bunun dışında kütüphanelerle ilgili bir amaç ya da eylem bulunmamaktadır. Oysa özellikle, "Eğitim ve İnsan Kaynakları" ile ilgili eylemlerde belirtilen amaçların gerçekleştirilmesinde kütüphane rol alan kurumlar arasında sayılmalıydı. Bilgi ve iletişim teknolojileri ve bu bağlamda bilgisayar okuryazarlığı eğitimini sadece okullarla sınırlayan ifadeler kütüphane kurumunun Bilgi Toplumu Politikasındaki yerini tam olarak algılayamayan bir yaklaşımı yansıtmaktadır. 10. Eylemde "Özürlüleri de içerecek şekilde, öğretmenler, öğrenciler ve ebeveynler için internet üzerinden eğitim destek hizmetleri, eğitimle ilgili kaynaklar ve e-öğrenim platformları sağlamak" (Bilgi Toplumu, 2010) amacından söz edilirken kütüphane kurumunun düşünülmemesi önemli bir yaklaşım sorununa işaret etmektedir. Aynı başlık altındaki 8. Eylemde, "Bilgi toplumunun gerektirdiği insan kaynağının yetiştirilmesi amacıyla bilgi teknolojilerine dayalı eğitim sistemlerinin yaygınlaştırılması gereği ve bu gereksinimin kamu kaynaklarının yanı sıra gönüllü kişi, kuruluş ve organizasyonların desteğiyle karşılanması yönünde düşünüldüğü" (Bilgi Toplumu, 2010) belirtilirken, yine ilgili görülen kuruluşlar arasında kütüphane kurumunun bulunmaması önemli bir kavrayış ve bakış açısı yetersizliğini yansıtmaktadır.

Kısaca belirtmek gerekirse, Türkiye'nin Bilgi Toplumu Politikası belgeleri arasında yer alan 2003-2004 Kısa Dönem Eylem Planı'nda kütüphane kurumuna ilişkin yaklaşım yetersizdir.

Kısa Dönem Eylem Planı́nın uygulamasının tamamlanmasından sonra, çalışma gruplarının katıımı ile orta vadeli Bilgi Toplumu Stratejisi'nin hazırlanmasına kadar uygulanmak üzere Yüksek PlanlamaKurulu'nun 24/3/2005 tarih ve 2005/5 sayılı kararı ile bir yıl süreli 2005 Eylem Planı hazırlanmış ve uygulanmıştır.2005 Eylem Planı'nda toplam 7 başlık altında 50 eyleme yer verilmiştir. Buna göre; Bilgi Toplumu Stratejisi başlığı altında 1, teknik altyapı ve bilgi güvenliğibaşlığı altında 6, eğitim ve insan kaynakları başlığı altında 10, hukuki altyapı başlığı altında 3, e-devlet başlığı altında 19, e-sağlık başlığı altında 5 ve e-ticaret başığı altında 6 eylem bulunmaktadır. 2005 Eylem Planı bir geçiş dönemi planı özelliğitaşımaktadır. Kısa Dönemli Eylem Planı́nda daha çok altyapıya yönelik eylemler yer alırken, 2005 Mayıs ayı itibariyle başlatılan 2005 Eylem Planı'nda mevcut gelişmeleri yaygınlaştırmayı hedef alan veya tamamlayıcı nitelikteki eylemlere yer verilmiştir (DPT, 2005a).

Plan incelendiğinde kütüphane kurumu ile ilgili ifadelerin yalnızca e-Devlet başlığı altında, Devlet Arşivleri Genel Müdürlüğü ile ilgili olarak geçmektedir. 


\begin{abstract}
“Devlet Arşivleri Genel Müdürlüğünce, kamuda elektronik ortamlarda üretilecek, kayıt altına alınacak, başka birimlere ya da kurumlara iletilecek, saklanacak ya imha edilecek elektronik bilgi ve belgelerin tabi olacağı usul ve esaslar ile kurumlarda oluşturulacak elektronik kayıt sistemlerinin birbiriyle uyumlu işlemesi ve etkin şekildeyönetilmesine ilişkin asgari standartların belirlenmesi hususlarında çalışmalar yapılacaktır" (DPT, 2005a).
\end{abstract}

biçiminde geçen açıklama 2003-2004 Kısa Dönem Planı́ndaki ifadenin devamı niteliğindedir. Bilgi Toplumu Politikasında kütüphane kurumuna ilişkin son derece sınırlı algılayışı yansıtan bu açıklama 2005 Eylem Planı́nın bu açıdan yetersizliği anlamına gelmektedir. Oysa daha önce de vurgulandığı üzere, kütüphane kurumu bu Plan'da da yer alan "eğitim ve insan kaynakları" başlığı altında gerçekleştirilmesi ön görülen eylemlerin kapsamına girmelidir. Bilgi okuryazarlığı becerisi sadece örgün eğitimde bulunan öğrenciler için değil toplumun tüm bireyleri için bir gereksinim niteliği taşımaktadır. Bu eğitimin özellikle örgün eğitim ile bağı kalmamış vatandaşlara verilmesinde halk kütüphaneleri birinci derecede işlev yüklenir. Sözü edilen başlık altında kamu çalışanları ve hatta ordudaki er ve erbaşların bilgi okuryazarı yapılması hedeflenirken, toplumun örgün eğitim ile bağı olmayan vatandaşların bu konuda eğitilmeleri hedefler arasına konulmamıştır. Kısaca, Plan'da kütüphanelerin bilgi okuryazarlığı konusundaki işlevlerinin farkında olunmadığı anlaşılmaktadır.

Plan'a ilişkin olarak yayımlanan ve genelde eylemlerin gerçekleşme oranlarını ele alan 2. Değerlendirme Raporu'nda (Devlet Planlama Teşkilatı, DPT, 2005b) Eğitim ve Insan Kaynakları başlığı altında yer alan 10 eylemden hiç birisinin sonuçlandırılamadığı dikkat çekmektedir. Plan'ın "eylemin sonuçlanması" düzeyindeki toplam gerçekleşme oranı ise 50 eylemden sonuçlanan iki'sinin karşılığı olarak \%4 olarak görünmektedir. Elbette bu raporun 2. Rapor olduğu da gözden kaçırılmamalıdır. 2005 Eylem Planı'na yönelik olarak hazırlanan ve Plan'ın son değerlendirilmesi anlamına gelen Sonuç Raporu (Devlet Planlama Teşkilatı, DPT, 2005c) incelendiğinde, Plan'da yer alan 50 eylemden toplam 19 tanesinin tamamlandığı, yani Plan'ın gerçekleşme oranının \%38 olduğu anlaşılmaktadır. Düşük sayılabilecek bu genel gerçekleşme oranı, kütüphane kurumunun en çok ilgili olduğu alan sayılabilecek "Eğitim ve İnsan Kaynakları"için iki tamamlanan eylem sayısı ile \%20'ye inmektedir. Bu veriler 2005 yılı için Türkiye'nin Bilgi Toplumu Politikasına yönelik olarak oluşturulan planın büyük ölçüde gerçekleştirilemediğini göstermektedir. Plan'ın sonuç değerlendirmesi anlamına gelen başarı ve başarısızlıkları şöyle belirtilmiştir:

\title{
Yeterlilikler/Başarılar
}

1. Bilgi Toplumu Stratejisi tamamlandı.

2. Bilgi toplumunun temelleri atıldı ve uygulamalara zemin hazırlandı.

3. BiT yatırımlarında etkinlik sağlandı ve mükerrerlikler önlendi. 
4. e-Devlet uygulamalarında büyük gelişmeler sağlandı. e-Devlet Ana Kapısı gibi önemli projelerin ihalesi gerçekleştirildi.

5. Ulusal ve uluslararası koordinasyon görevi yerine getirildi.

6. Kurumlarda, işletmelerde ve vatandaşlarda bilgi toplumu kültürü oluşmaya başladı.

\section{Yetersizlikler/Başarısızlıklar}

1. Yerel yönetimlere ilişkin konularda koordinasyon güçlükleri yaşandı.

2. Sayısal erişim (Bilgisayar, İnternet) maliyetleri hala yüksek düzeyde (DPT, 2005c).

Görüldüğü gibi, Plan'a yönelik iç değerlendirmeler oldukça olumlu bir içeriktedir. Ancak, biz bu değerlendirmenoktalarının en azından bir bölümünütartışılırgörmekteyiz. "Bilgi Toplumunun temelleri atılı" gibi sonuçlar, verilerle ortaya konamadığı gibi, bir hayli de iddialı görünmektedir. Aynı biçimde, son maddede dile getirilen "Kurumlarda, işletmelerde ve vatandaşlarda bilgi toplumu kültürü oluşmaya başladı" değerlendirmesi doğruluk payı taşımakla birlikte tartışılabilir. Yetersizliklerde belirtilen noktalardan ikincisi ise kütüphane kurumunu yakından ilgilendiren bir konudur ve bu nedenle bir olumsuzluğu ortaya koymaktadır.

Sonuç olarak, küçük bir gerçekleşme oranına sahip 2005 Eylem Planı kendisinden önceki politika belgelerine göre kütüphanelere yaklaşım açısından daha zayıf bir içeriğe sahip olduğu ve Türkiye'nin Bilgi Toplumu Politikasına katkısının sınırlı olduğu söylenebilir. Elbette, bir yıl süreli bir plandan daha büyük bir katkı beklemek de gerçekçi görünmemektedir.

\section{Bilgi Toplumu Stratejisi 2006-2010 ve Bilgi Toplumu Stratejisi: Eylem Planı 2006-2010'da Kütüphane Kurumuna Yaklaşım}

2005 Eylem Planının uygulanması sonrasında 2005-2006 yıllarında hazırlanan Bilgi Toplumu Stratejisi 2006-2010 ve bu belgenin yaşama geçirilmesinde yapılacaklar listesi anlamına gelen eki Eylem Planı, 11/07/2006 tarih ve 2006/38 sayılı Yüksek Planlama Kurulu Kararı'yla onaylanmış olup, 28/07/2006 tarih ve 26242 sayılı Resmi Gazete'de yayımlanarak, aynı tarihten itibaren yürürlüğe girmiştir (Devlet Planlama Teşkilatı, DPT, 2006a; Devlet Planlama Teşkilatı, DPT, 2006b).

Bu iki belgenin buraya kadar incelenen diğerlerinden farklı olduğu söylenebilir. Öncelikle, bu iki belge daha uzun bir dönemi hedeflemektedir. İkincisi; belge, içerikolarak da diğer politika belgelerine göre daha kapsamlıdır. Son olarak; daha önce hazırlanan ve bu çalışmada ele aldığımız belgeler, bu belgenin hazırlık belgeleri niteliğindedir. Bir başka deyişle, Bilgi Toplumu Stratejisi 2006-2010 bazı hazırlık aşamalarından sonra ortaya çıkan, olgunlaştııılmış bir politika belgesidir. Dolayısıyla, bu belge, Türkiye'nin bu çalışmaya konu olan politikasını ve bu politika bağlamında kütüphane kurumuna 
yaklaşımını en kapsamlı olarak değerlendirebileceğimizpolitika belgesidir. Belge'nin önemi, "Bilgi Toplumu Stratejisi ve eki Eylem Planı; vatandaşlar, kamu kesimi ve iş dünyası ile sivil toplum kuruluşları, kısacası toplumun her kesimi için önümüzdeki 5 yıllık dönemde temel referans belgesi olacak ve gelecekte yürütülecek çalışmalara da ışık tutacaktır" biçiminde belirtilmiştir (DPT, 2006a).

Türkiye'nin Bilgi Toplumu temel Politika belgesi sayılabilecek Bilgi Toplumu Stratejisi 2006-2010 şu başlık ve alt başlıklardan oluşmaktadır:

1. Türkiye'nin Önündeki Bilgi Toplumu Fırsatı

2. 2010 Yılına Doğru Türkiye'nin Potansiyeli

2.1. Vatandaşlar

2.2. İşletmeler

2.3. Devlet

2.4. Bilgi ve İletişim Teknolojileri Sektörü

2.5. Ar-Ge ve Yenilikçilik

3. Türkiye'nin Stratejik Öncelikleri

3.1. Sosyal Dönüşüm

3.2. Bilgi ve Illetişim Teknolojilerinin İş Dünyasına Nüfuzu

3.3. Vatandaş Odaklı Hizmet Dönüşümü

3.4. Kamu Yönetiminde Modernizasyon

3.5. Küresel Rekabetçi Bilgi Teknolojileri Sektörü

3.6. Rekabetçi, Yaygın ve Ucuz Iletişim Altyapı ve Hizmetleri

3.7. Ar-Ge ve Yenilikçiliğin Geliştirilmesi

4. Stratejinin Uygulanması

4.1. Kurumsal Yapılanma ve Yönetişim

4.2. Eylem Planlaması

4.3. Iletişim

4.4. Ölçümleme ve Değerlendirme 5. Uluslararası Ilişkiler (DPT, 2006a)

Görüldüğü gibi, DPT Türkiye'nin Bilgi Toplumu Politikasını 5 ana başıkta ele almıştır. Illk iki bölüm Bilgi Toplumu konusunda Türkiye'ye ilişkin var olan durum saptaması niteliğindedir. Türkiye'nin Bilgi Toplumu konusundaki potansiyeli "vatandaşlar, 
işletmeler, devlet, BiT sektörü ve Ar-Ge/Yenilikçilik" başlıkları altında değerlendirilmiştir. Bu potansiyel değerlendirmesi çerçevesinde kütüphane kurumuna, özellikle bilgi okuryazarlığı ile BiT kullanım becerisi ve olanağı yaratma bağlamında "vatandaşlar"; bilgi edinme özgürlüğünü kullanabilme açısından "devlet" ve ulusal araştırma altyapısının bir kurumu olması nedeniyle de "Ar-Ge/Yenilikçilik" başlıkları altında yer verilmesi beklenir. Belge'nin sözü edilen "vatandaşlar" bölümü incelendiğinde "vatandaşların bilgi ve iletişim teknolojilerinin sağlayacağı faydalar konusunda bilinçlendirilmesi, erişim imkânlarının sağlanması ve bu teknolojileri kullanma yeteneğinin kazandırılması gerekmektedir" belirlemesi dikkat çekicidir (DPT, 2006a). Bu belirleme kuramsal olarak kütüphane kurumuna güçlü gönderme yapan bir yaklaşımın ifadesidir. Ancak, bu bölümde bu ifadeye dayalı tek bir kütüphane terimi geçmemektedir. Konu daha çok vatandaşların İnternet erişim olanaklarına yönelik istatistiksel veriler üzerinde yoğunlaştııılmıştır. Dolayısıyla, "kütüphane kurumu, Türkiye'nin Bilgi Toplumu Stratejisi gibi temel bir belgesinde vatandaşlara BiT kullanma beceri ve olanakları yaratma bağlamında düşünülmemektedir" yorumu yanlış olmayacaktır. Bu bölümün "devlet" kısmına bakıldığında, konunun, "bilgi toplumuna dönüşüm sürecinde kamu hizmetlerinin, vatandaşlar ve iş dünyasının ihtiyaç ve beklentilerine uygun olarak, bilgi ve iletişim teknolojilerinin de yardımıyla etkin, hızlı, kaliteli, sürekli, güvenilir, şeffafve bütünleşikşekilde sunumu ve iş süreçlerinde etkinlik" bağlamında ele alındığı anlaşılmaktadır (DPT, 2006a). Bu bölümde konuya ilişkin yapılan değerlendirmelerde kamu hizmetlerinden elektronik ortama aktarılanlar, kamudaki bilgi paylaşımı ve vatandaş odaklı yaklaşımlardan söz edilmekte, ancak kütüphane kurumu ile bir bağlantı kurulmamaktadır. Aynı yaklaşım yetersizliğinin "Ar-Ge ve Yenilikçilik" kısmı için de söz konusu olduğu söylenebilir.

Bilgi Toplumu Stratejisi 2006-2010'da Türkiye'nin Bilgi Toplumu oluşturmaya yönelik stratejik öncelikleri şöyle sıralanmıştır:

\section{Sosyal Dönüşüm}

2. Bilgi ve Iletişim Teknolojilerinin İş Dünyasına Nüfuzu

3. Vatandaş Odaklı Hizmet Dönüşümü

4. Kamu Yönetiminde Modernizasyon

5. Küresel Rekabetçi Bilgi Teknolojileri Sektörü

6. Rekabetçi, Yaygın ve Ucuz Iletişim Altyapı ve Hizmetleri

7. Ar-Ge ve Yenilikçiliğin Geliştirilmesi

Türkiye'nin Bilgi Toplumu potansiyelinin değerlendirildiği bir önceki bölümde olduğu gibi, bu bölümde de kütüphane kurumuna ilişkin yaklaşımın görülmesi gereken başlıklar bulunmaktadır. Başta, herkes için bilgi ve iletişim teknolojileri fırsatı yaklaşımına dayandırılan "Sosyal Dönüşüm" olmak üzere, özellikle, "Vatandaş Odaklı 
Hizmet Dönüşümü" ve "Ar-Ge ve Yenilikçiliğin Geliştirilmesi" bölümleri kütüphane algısının bulunması gereken kısımlarıdır. Sözü edilen kısımlar incelendiğinde, belirtilen bölümlerde kütüphane kurumuna ilişkin sadece şu ifadenin yer aldığı görülmektedir: "Kütüphane hizmetleri, katalog tarama ve içeriğe erişim hizmetleri elektronik ortamda sunulur hale getirilecektir." Bu açıklama, bazı olumluluklar taşımakla birlikte, kütüphane kurumunun Türkiye'nin Bilgi Toplumu Politikası içindeki dönüşümünün ve dolayısıyla işlevinin, daha önce diğer belgelerdeki yaklaşıma benzer biçimde sadece "kaynak ve hizmetlerin elektronik ortama aktarılması" bağlamında ele alındığını ortaya koymaktadır.

"Sosyal Dönüşüm" kısmında Kamu İnternet Erişim Merkezlerinin kurulacağından, “Vatandaş Odaklı Hizmet Dönüşümü"nde vatandaşların elektronik kamu hizmetlerine 7 gün 24 saat ve tercih ettikleri kanallar aracılığıyla ulaşabileceklerinden ve "Ar-Ge ve Yenilikçiliğin Geliştirilmesi"nde de araştırma etkinliklerinin destekleneceğinden ve artırılacağından söz edilirken kütüphane kurumuna ilişkin bir gönderme görülmemektedir.

Belge'nin "Stratejinin Uygulanması" ve "Uluslararası İlişkiler" bölümlerinde de kütüphane kurumu ile ilgili herhangi bir ifade geçmemektedir.

Sonuç olarak, Türkiye'nin en ciddi politika belgesinde kütüphane kurumuna ilişkin tek ifadenin yukarıda alıntılanan ve kütüphane kaynak ve hizmetlerinin elektronik ortama aktarılmasını öneren cümle olması son derece ciddi bir yaklaşım yetersizliğini ve eksikliğini ortaya koymaktadır. Bu yoruma dayanarak, Türkiye'nin Bilgi Toplumu Politikasında kütüphane kurumuna ilişkin yaklaşımın son derece yetersiz olduğu söylenebilir.

Bilgi Toplumu Stratejisi Eylem Planı: 2006-2010, adlı politika/strateji belgesi yukarıda değerlendirilen Bilgi Toplumu Stratejisi 2006-2010 adlı belgede ortaya konulan hedeflerin gerçekleşmesini sağlayacak eylemleri içermektedir. Bilgi Toplumu Stratejisi 2006-2010'un eki olan bu belge de konumuz açısından son derece önemli görünmektedir. Eylem Planı'nın genel yapısı Strateji Belgesi ile koşutluk göstermekte, aynı sistematik yaklaşım içinde hazırlandığı anlaşılmaktadır. Belge'de ön bilgi niteliğinde bazı değerlendirmeler yapıldıktan sonra, Strateji Belgesindeki 7 bölüm çerçevesinde yapılması planlanan eylemler sıralanmaktadır (DPT, 2006b). Bu önemli belgede toplam 111 eylem planlanmıştır. Bunlar arasında kütüphane kavramının geçtiği iki eylem "Sosyal Dönüşüm" başlığı ve "Yaygın Eğitim" alt başlığı altında Okullarda Bilgi Teknolojileri (BT) Altyapısı adlı 1. Eylem ile sorumlu kuruluş olarak Kültür ve Turizm Bakanlığı'nın gösterildiği “Eğitim ve Kültür Hizmetleri" başlığı ve Entegre e-Kütüphane Sistemi alt başlığı altında verilen 38. Eylemdir. 1.Eylem'in açıklamasında kütüphane ile ilgili şu ifade geçmektedir: "BT laboratuvarlarının planlanan tüm okullarda kurulumu hızla tamamlanacak ve bu laboratuvarlarda çoklu ortam kütüphaneleri oluşturularak güncelliği sağlanacaktır." 38.Eylem açıklamasında ise üç madde yer almaktadır: 
$\diamond$ "Ülkedeki tüm kütüphanelerde yer alan kaynakların tek noktadan sorgulanabilmesi; kitap ayırtma, talep, uzatma, ceza ödeme gibi işlemlerin çevrimiçi gerçekleştirilebilmesi; elektronik kanallardan kullanııılara çeşitli bilgilendirme mesajları yollanabilmesini sağlayacak sistem kurulacaktır.

$\diamond$ Seçili kütüphane materyallerine (kitap, tez, saydam, vb.) ve devlet arşivlerinde yer alan sık kullanılan belgelere çevrimiçi erişim imkanı sağlanacaktır.

$\diamond$ Farklı kurumlar tarafından yürütülen e-kütüphane çalışmaları birleştirilecektir."

Gerek 1. Eylem ve gerekse 38.Eylemde yer alan açıklamalar kütüphane kurumu açısından yetersiz ancak görece olumlu bir duruma işaret etmektedir. Bilgi Toplumu Politikasının yaşama geçirilmesinde kütüphane kurumunun 2 eylemde düşünülmesi ve bağlamlarının "Sosyal Dönüşüm" ve "Eğitim ve Kültür Hizmetleri" olması kütüphaneye ilişkin bir algıyı yansıtmaktadır. Yine, elektronik kütüphane bakışı bir yaklaşımla ve kanımızca beş yıllık bir süreçi çin çok da gerçekçi olmayan hedefler söz konusudur. Üstelik bu hedeflerin gerçekleşmesi için 2006 yılı başlangıç olarak verilmiş ve gerçekleşme süresi de 24 ay olarak belirlenmiştir. Söz konusu hedeflerin, gerçekleşmesi planlanan yıl bir yana, bu makalenin de yazıldığı yıl olan 2010'da öngörülenin çok uzağında olunduğu açıktır. Kısaca, 2006-2010 yılları arasında Türkiye'nin Bilgi Toplumu Politikasında kütüphaneler ilişkin olarak konulan hedeflerin "e" içerikli, olumlu ancak yetersiz olduğu, gerçekçi olmadığı ve zaten gerçekleşmediği de söylenebilir.

Eylemlerin gerçekleşme durumlarına ilişkin değerlendirmelerin yapıldığı raporların sonuncusu olan 5. Raporda (DPT Bilgi Toplumu Dairesi, 2010). Bilgi Toplumu Stratejisi 2006-2010'da konulan hedeflerin gerçekleşme durumuna ilişkin genel tablo;

"2009 yılı sonu itibarıyla Eylem Planının gerçekleşme durumu farklı acılardan değerlendirilmiştir. Eylemlerin ilerleme aşamaları dikkate alındığında, eylemlerden 22 adedinin (\%20) tamamlandığı, 62 eylemin (\%56) çalışmalarında önemli aşama kaydedildiği ve 19 eylem (\%17) ile ilgili çalışmaların ise henüz başlangıç aşamasında olduğu görülmektedir. Ayrıca, sorumlu kuruluşların katkılarıyla her eylem için 0 ila 100 arasında değişen tamamlanma yüzdesi belirlenmiştir. Bu bağlamda, her bir eylemin tamamlanma yüzdesi dikkate alınarak hesaplanan ortalama tamamlanma oranı yüzde 49,65 olarak belirlenmiştir"

biçiminde özetlenmiştir.

Kütüphane kurumunu ilgilendiren 1 ve 38.Eylemlerin gerçekleşme durumlarına bakıldığında, 1. Eylemin \%100 tamamlandığı, Kamu Internet Erişim Merkezleri Kurulumunun \%40 oranında gerçekleştiği ve 38.Eylemde yer alan Entegre e-Kütüphane Sistemi hedefinin ise \%66 oranında tamamlandığı belirtilmektedir. Bu gerçekleşme oranlarına ilişkin değerlendirmelerin tartışıır göründüğünü düşünmekteyiz. Özellikle, 
Entegre e-Kütüphane Sistemine ilişkin \%66'ık gerçekleşme oranı kuşkuludur. Bu oranın nasıl bir değerlendirme ile belirlendiği açık olmamakla birlikte, ülkedeki kütüphane hizmetlerine ilişkin veri ve gözlemlerimiz bunun böyle olmadığını düşündürtmektedir.

Bu bölümde çeşitli resmi politika/strateji belgelerine dayanarak kütüphane kurumuna yönelik olarak yapılan değerlendirmelerde ortaya konabilecek ana bulgu; Türkiye'nin Bilgi Toplumu politikasında kütüphane kurumuna ilişkin yaklaşımın yetersiz ve bütünsel bir algılayıştan yoksun oluşu ve bu kurumun ilgili politikada organik bir bileşen olarak görülmemesidir.

\section{Sonuç ve Öneriler}

Çalışmada elde edilen bulgu ve değerlendirmeler çerçevesinde şu sonuçlara ulaşılmıştır:

1. Kütüphane kurumu, Türkiye'nin Bilgi Toplumu Politikasını oluşturma sürecinin başlangıcında (2002e-Türkiye çalışmalarında) bu politikanın bir parçası olarak görülmüştür.

2. Türkiye'nin Bilgi Toplumu Politikasında çok önemli sayılabilecek e-Dönüşüm Türkiye Projesi'nde kütüphane kurumu ile ilgili doğrudan bir yaklaşım bulunmamaktadır.

3. Bilgi Toplumu Politikasınıne-Dönüşüm Türkiye Projesi bağlamındaki örgütlenme altyapısında kütüphane ve kütüphaneciye "sınırlı" ölçüde yer verilmiştir.

4. Türkiye'nin Bilgi Toplumu Politikasında arşiv ve kütüphanelerden beklenen ana işlev, genelde, bu kurumlardaki kaynak ve hizmetlerin elektronik ortama aktarılarak erişime açılmasıdır. Bu, bir anlamıla olumlu olmakla birlikte, Bilgi Toplumu Politikasında kütüphanelere ilişkin işlevlerin belirli ölçüde sınırlanması anlamına da gelmektedir.

5. Bilgi Toplumu Politikası belgelerinde toplumun bilgi teknolojisi eğitimi konusunda kütüphaneler ilgili kurumlar arasında yer almamakta, bu konuda kütüphanelerin işlev yüklenebilecekleri ve hatta yüklenmeleri gerektiği düşünülmemektedir. Genel olarak söylemek gerekirse, Türkiye'nin Bilgi Toplumu Politikasının eğitim boyutunda kütüphane kurumu bulunmamaktadır.

6. Türkiye'nin Bilgi Toplumu Politikasında Kültür Bakanlığı ve bağlı birimleri rol üstlenebilecek kurumlar olarak genelde düşünülmemiştir.

7. Türkiye'nin Bilgi Toplumu Politikası belgeleri arasında yer alan 2003-2004 Kısa Dönem Eylem Planı'nda kütüphane kurumuna ilişkin yaklaşım yetersizdir.

8. 2005 Eylem Planı bir Politika belgesi olarak kütüphane kurumunu doğru ve yeterli bir yaklaşımla ele almamıştır. Ayrıca, Plan, kendisinden önceki politika belgelerine göre kütüphanelere yaklaşım açısından daha zayıf bir içeriğe sahiptir. 
9. Politika belgeleri arasında kütüphane kurumuna yaklaşım açısından bazı istikrarsızlık, tutarsızlık ve orantısızlıklar bulunmaktadır. Bazı belgelerde kütüphane kurumuna ilişkin yeterli ve doğru bir yaklaşım söz konusu iken diğer bazılarında tam tersi bir durum görülebilmektedir. Bir başka deyiş̧le, Türkiye'nin Bilgi Toplumu Politikası ile ilgili yaklaşımında kütüphane kurumu ile ilgili sürekli bir duyarlılık bulunmamaktadır. Bu konuda istikrar, süreklilik ve bütünlükten yoksun bir yaklaşım söz konusudur.

10. Türkiye'de Bilgi Toplumu Politikasına yönelik olarak hazırlanan planların genelde gerçekleştirilememe ya da küçük bölümünün gerçekleştirilebilmesi sorunu bulunmakta, bu da doğal olarak kütüphane kurumuna yönelik uygulamaları olumsuz etkilemektedir.

11. Türkiye'nin Bilgi Toplumu Stratejisi 2006-2010 belgesinde, kütüphane kurumu, vatandaşlara BiT kullanma beceri ve olanakları yaratma, vatandaşların kamu hizmetlerinden etkin biçimde yararlanmaları, Ar-Ge ve Yenilikçilik bağlamlarında düşünülmemiştir.

12. Bilgi Toplumu Stratejisi 2006-2010, Türkiye'de kütüphane kurumunun Bilgi Toplumu içindeki dönüşümünü ve dolayısıyla işlevini, daha önce diğer belgelerdeki yaklaşıma benzer biçimde sadece "kaynak ve hizmetlerin elektronik ortama aktarılması" ile sınırlamıştır. Bu ana belgenin tümünde kütüphane kurumuna ilişkin olarak "Kütüphane hizmetleri, katalog tarama ve içeriğe erişim hizmetleri elektronik ortamda sunulur hale getirilecektir" biçiminde geçen tek ifade sözü edilen sınırlılığı açıkça ortaya koymaktadır.

13. Türkiye'nin Bilgi Toplumu Stratejisi Eylem Planı 2006-2010'da kütüphanelere ilişkin olarak konulan hedeflerin "e"içerikli, olumlu ancak yetersiz olduğu, gerçekçi olmadığı ve gerçekleşmediği de söylenebilir.

14. Bilgi Toplumu Stratejisi Eylem Planı (2006-2010) Değerlendirme Raporlarında kütüphanelere ilişkin olarak konulan hedeflerin gerçekleşme oranları kuşkulu görünmektedir.

15. Türkiye'nin Bilgi Toplumu Politikasında kütüphane kurumuna ilişkin mühendislik nitelikli bir yaklaşım bulunmaktadır.

Kısaca söylemek gerekirse, kütüphane kurumu Türkiye'nin Bilgi Toplumu Politikasında organik bir bileşen olarak görülmemektedir. Sözü edilen stratejide bu kurumu toplumsal, kültürel ve eğitimsel bağlamlarda doğru algılayan bütünsel bir yaklaşım bulunmamaktadır.

Ulaşılan bu sonuçlara dayanarak şu öneriler sunulabilir:

$\diamond$ Kütüphaneler ve kütüphaneciler Bilgi Toplumu Politikalarının kendi varlık süreçleri için belirleyici olacağının farkında olmalıdırlar. Gerek akademisyen 
ve gerekse uygulamada yer alan kütüphaneciler Türkiye'de Bilgi Toplumu Stratejilerinin/ Politikalarının oluşum ve uygulanma süreçlerine etkin olarak katılmalıdır. Bu katılımın mesleki dernekler ve lider kütüphaneler aracılığıyla kurumsal ve etkili kişiler aracılığıyla da kişisel düzeyde gerçekleştirilmesi sonuç alma açısından daha uygun olacaktır. Elbette bu katılımda süreklilik ve kurumsallık önemli görünmektedir.

$\diamond$ Kütüphaneciler bu konuda politika oluşturucu ve uygulayıcılarla daha yakın ilişkiler geliştirmelidirler.

$\diamond$ Gerek politika süreçlerine katılımcı olmak ve gerekse politika oluşturucularla yakın ilişkiler geliştirmede "Kütüphane kurumunun Bilgi Toplumu Politikasındaki yeri”ne yönelik profesyonel bir süreçle yaratılmış yazılı rapor vb. politikaların varlığı zorunludur. Kütüphaneciler öncelikle kendileri bu konuda talep ve yaklaşımlarını bilimsel bir biçimde ortaya koymalıdırlar. Bu nedenle, ilgili kişi ve kurumların katkılarıyla ve mesleki kuruluşlar aracılığıyla "Türkiye'nin Bilgi Toplumu Politikasında Kütüphane Kurumunun Yeri" konusunda kapsamlı bir politika belgesi hazırlanmalıdır. Bunun için başlangıç adımı olarak da bu konuda kapsamlı bir bilimsel toplantı düzenlenebilir.

$\diamond$ Burada makale düzeyinde yapılan bu çalışmanın genişletilmesi ve hatta doktora düzeyinde bir çalışmaya dönüştürülmesi, sözü edilen politika belgesine de kaynaklık edebilecektir.

Türkiye'de hemen her alanda olduğu gibi, Bilgi Toplumu olma çabasında da günübirlik, bütünsellikten yoksun, kişisel duyarlılıklara dayalı ve güncel politika gereksinimlerine uygun davranış ve yaklaşımlar sonuç alıcı ve geliştirici olamayacaktır. Bu konuda sürecin farkında olmak, bir başka deyişle sürece duyarlı olmak son derece önemlidir. Aksi takdirde, örneğin 500 yıl sonra, Türkiye'nin bu dönemine ilişkin olarak yapılacak değerlendirmelerde, tıpkı matbaanın Osmanlıya yaklaşık 250 yıl geç girişinin etkilerini hala tartıştığımız gibi, bu sürecin kaçırılışı da tartışılıyor olacaktır.

\section{Kaynakça}

Akın, H. B. (2005). Yeni ekonomi. İstanbul: Çizgi Kitabevi.

Akın, H. B. (2007). Dünü ve geleceğiyle bilgi toplumu. H. Odabaş ve H. Anameriç (Yay. Haz). Bilgi içinde (ss. 1-22). Ankara: Referans Yayıncılık.

Alkan, N. (1997). Üniversite kütüphaneleri ve ulusal bilgi politikası. Türk Kütüphaneciliği, 11(3), 233252.

Bilgi Toplumu (2010). 16 Eylül 2010 tarihinde http://www.bilgitoplumu.gov.tr adresinden erişildi.

Bilişim ve Ekonomik Modernizasyon Raporu (1998-2002). E-ticaret koordinasyon kurulu ve kamunet. 16 Eylül 2010 tarihinde http://www.bilgitoplumu.gov.tr/Portal.aspx? adresinden erişildi. 
De Beer, J. A. (2005). Open access scholarly communication in South Africa: current status, significance and the role for national information policy in the national system of innovation. Stellenbosch: Universty of Stallenbosch.

Devlet Planlama Teşkilatı (DPT). (2005a). e-dönüşüm Türkiye projesi 2005 eylem planı değerlendirme raporu I. 20 Eylül 2010 tarihinde http://www.bilgitoplumu.gov.tr/ Documents/1/2005_Eylem_ Plani/050900_1.DegerlendirmeRaporu.pdf adresinden erişildi.

Devlet Planlama Teşkilatı (DPT). (2005b). e-dönüşüm Türkiye projesi 2005 eylem planı değerlendirme raporu II. 20 Eylül 2010 tarihinde http://www.bilgitoplumu.gov.tr/ Documents/1/2005_Eylem_ Plani/051200_2.DegerlendirmeRaporu.pdf adresinden erişildi.

Devlet Planlama Teşkilatı (DPT). (2005c). e-dönüşüm Türkiye projesi 2005 eylem planı sonuç raporu. 20 Eylül 2010 tarihinde http://www.bilgitoplumu.gov.tr/Documents/1/2005_Eylem_ Plani/060500_SonucRaporu.pdfadresinden erişildi.

Devlet Planlama Teşkilatı (DPT). (2006a). Bilgi toplumu stratejisi (2006-2010). 20 Eylül 2010 tarihinde http://www.bilgitoplumu.gov.tr/Documents/1/BT_Strateji/Diger/060700_BilgiToplumu StratejiBelgesi.pdf adresinden erişildi.

Devlet Planlama Teşkilatı (DPT). (2006b). Bilgi toplumu stratejisi eylem planı (2006-2010). 20 Eylül 2010 tarihinde http://www.bilgitoplumu.gov.tr/Documents/1/BT_Strateji/Diger/060700_ EylemPlani.pdf adresinden erişildi.

Devlet Planlama Teşkilatı Bilgi Toplumu Dairesi. (2010). Bilgi toplumu stratejisi eylem planı (20062010) değerlendirme raporu V. 20 Eylül 2010 tarihinde http://www.bilgitoplumu.gov.tr/ Documents/1/BT_Strateji/20100323_BTS_Degerlendirme_V.pdf adresinden erişildi.

Duff, Alistair S. (2004). The past, present, and future of information policy. Information, Communication \& Society, 7(1), 69-87.

Eczacıbaşı, F. (2006). Bilgi toplumu stratejisi neden gerekli? Türk Kütüphaneciliğ, 20(2), 203-206. e-Ticaret Koordinasyon Kurulu (1998-2002). 16 Eylül 2010 tarihinde http://www.bilgitoplumu. gov.tr/Portal.aspx? adresinden erişildi

Fenerci, T. (2004). Bilgi politikaları açısından kapitalist ekonomik sistemde bilgi toplumu olgusu. Bilgi Dünyasi, 5(1), 74-92.

Gültan, S. (2003). Bilgi toplumu sürecinde Avrupa Birliği ve Türkiye. Ankara: Ankara Üniversitesi.

IFLA (2010). WSIS-world summit on the Information society. 16 Ağustos 2010 tarihinde http://www. ifla.org/files/wsis/Documents/libraries-and-the-wsis-action-lines-en.pdf adresinden erişildi.

Işık, Y. (2007). Bilgi ekonomisi ve Türkiye ekonomisinin gelişme perspektifi. H. Odabaş ve H. Anameriç (Yay. Haz). Bilgi içinde (ss.81-98). Ankara: Referans Yayıncılık.

KamuNET (1998-2002). 16 Eylül 2010 tarihinde http://www.bilgitoplumu.gov.tr/Portal.aspx? Adresinden erişildi.

Külcü, Ö. (2001). Toplumsal ve ekonomik değişim sürecinde bilgi ve bilgi hizmetleri. Türk Kütüphaneciliği, 15(1), 3-19.

Montviloff, V. (1990). National information policies. Paris: UNESCO.

Rao, S. S. (2005). Bridginig digital divide: Efforts in India, Telematicsand Informatics, 22, 361-375. 
Rehman, S. U. (1996). Information policies for developing nations: A framework for analysis applied to Malaysian and Indian information policies. Libri, 46(4), 184-195.

Rossel, S. A. (1997). Governing in an information society. Technological Forecasting and Social Change, 54, 29-35.

Stevenson, N. (2003). Cultural citizenship: Cosmopolitan questions. Berkshire: Open University.

T.C. Başbakanlık (2002a). e-Türkiye girişimi eylem planı. 16 Eylül 2010 tarihinde http://www. bilgitoplumu.gov.tr/Documents/1/Yayinlar/020800_E-TurkiyeEylemPlani.pdf adresinden erişildi.

T.C. Başbakanlık (2002b). e-Türkiye girişimi I. ara rapor. 20 Eylül 2010 tarihinde http://www. bilgitoplumu.gov.tr/Documents/1/Yayinlar/020500_E-TurkiyeGirisimi1.AraRaporu.pdf adresinden erişildi.

Toffler, A. (1981). Üçüncü dalga. (A. Seden Çev.). İstanbul: Altın Kitaplar.

Tonta, Y. ve Küçük, M. E. (2005). Sanayi toplumundan bilgi toplumuna geçiş sürecinde temel dinamikler. Türk Kütüphaneciliği, 19(5), 449-464.

Toplu, M. (1999). Türkiye'de ulusal enformasyon ve bilim politikaları alanındaki yaklaşımlar. Türk Kütüphaneciliği, 13(4), 335-362.

Toplu, M. (2007). Ulusaldan evrensele enformasyon politikası: süreçler, değişimler. H. Odabaş ve H. Anameriç (Yay. Haz). Bilgi içinde (ss.129-166). Ankara: Referans Yayıncılık.

TÜBITAK. (1983). Türk bilim politikası: 1983-2003. Ankara: TÜBiTAK.

TÜBITAK. (1993). Türk bilim ve teknoloji politikası:1993-2003. Ankara: TÜBITAK.

Türk Dil Kurumu. (2010). Politika. 16 Eylül 2010 tarihinde http://tdkterim.gov.tr/bts/ ?kategori=ver ilst\&kelime=politika\&ayn $=$ tam adresinden erişildi.

Türkiye Ulusal Enformasyon Altyapısı Anaplanı (TUENA). 16 Eylül 2010 tarihinde http://www. bilgitoplumu.gov.tr/Portal.aspx? adresinden erişildi.

Uçkan, Ö. (2006). Bilgi politikası ve bilgi ekonomisi: Verimlilik, istihdam, büyüme ve kalkınma. Bilgi Dünyası, 7(1), 23-48.

Weinberg, A. M. (1963). Science, government and information: the responsibilities of the technical community and the government in the transfer of information. Washington, D.C: US GPO.

Weingarten, F. W. (1996). Technological change and the evolution of information policy. American Libraries, 27(11), 45-47. 